\title{
Conditions of the Operations of Local Government Units in Unstable Economic Environments
}

\author{
Małgorzata Dworakowska"
}

\begin{abstract}
Purpose - The goal of this article is to present conditions for the operation of Poland's local government units in the 2007-2016 period from the perspective of these entities' finances. The subject is considered with regard to major changes which took place in the economic environment of local government units in the past few years.

Design/methodology/approach - Such a complex study area requires various research methods to be applied in order to achieve the planned goal. The research procedure includes nonreactive research, a comparative historical approach and an analysis of official documents.

Findings - The analyses performed revealed the conditions of Polish local government units in 2007-2016 regarding the finances of these entities. The collected data points to frequent changes to the units' economic environment which require that the new challenges be appropriately addressed. An unstable economic setting shapes the conditions of the operations of gminas, cities with powiat rights, powiats and voivodships. Consequently, it uniquely affects the activities of local government units.

Originality/value - the analyses of the subject confirm that the operations of local government units are affected by various stimuli coming from the economic environment. For the past few years it underwent dynamic changes that made local government entities react to them and stand up to emerging challenges. Local government units' operations are determined by a group of interrelated conditions. The analysis of the operations of local government units in Poland in 2007-2016 indicates that finances are the foundation of the functioning of each local government unit and an indicator of reality and success of the public tasks performed.
\end{abstract}

Keywords: condition of operations, local government units, economic environment, finances

\section{Introduction}

Local government units constitute important components of the public sector and their operations are affected by various factors coming from the economic environment, which has been changing extraordinarily during the past few years. The term economic environment should be understood as a space which local government units operate within and which is affected by economic, legal and political factors, among others. It encompasses all items present within the realm of the local government unit's economic space, affects its financial situation and shapes the conditions of the operations of gminas, cities with powiat rights, powiats and voivodships and also forces quick reactions to new challenges.

\footnotetext{
* Małgorzata Dworakowska PhD, Warsaw School of Economics, Collegium of Socio-Economics, al. Niepodległości 162,02-554 Warsaw,mdwora@sgh.waw.pl.
} 
The purpose of this article is to present conditions of the operations of local government units in Poland during the 2007-2016 period from the perspective of these units' finances. The topic is considered taking into account all major changes affecting the economic setting of local government units.

\section{Functioning of Local Government Units}

Local government units play an important role in the accomplishment of public tasks. Multiple layers and the complexity of tasks performed by the public, the local government sector demands searching for solutions that ensure optimal conditions for the realisation of these tasks. These may be investment or non-investment tasks. Decision-making aimed at the performance of public tasks entrusted to local government units require the creation of foundations to ensure essential financial resources. Accomplishment of a wider and wider catalogue of commissioned tasks depends on the budgetary abilities of local government units. These abilities rely on amounts allocated in revenue and income budgets as well as the total expenditure and outgoings incurred. Revenue and income provisioned in local government units' budgets are forecasts, while expenditure and outgoings set an impassable limit.

An extraordinarily important component of local government units' financial management is own revenue ${ }^{1}$, which should be the financial base. This means that their share in the total revenue structure of each local government unit should be as big as possible. Individual categories of local government units' own revenue are diverse, however (cf. GłowickaWołoszyn et al., 2017, pp. 396-398). The major group of own revenue includes amounts collected from taxes and charges. When analysing the share of own revenue in the total revenue of local government units in the 2007-2016 period (Table 1) one must point out that their biggest share was reported in gminas in 2015 (49.7\%), in cities with powiat rights in 2007 (70.3\%), in powiats in 2016 (35.4\%), and in voivodships in 2007 (68.3\%). The share of own revenue in total revenue in cities with powiat rights was impressive (over a half of the budget revenue); despite the fact it was continuously dropping in 2007-2012 and in 2016 compared to the previous year. However, own revenue was not the most significant component of the finance systems of powiats as their revenue structures were dominated by supplementary revenue components. The reason for this is a narrow catalogue of own revenue due to powiats, which makes them seek supplementary revenue to finance their entrusted tasks. In 2007-2008 and in 2016 own revenue constituted more than a half of the budget revenue of voivodships. A data analysis reveals that the best revenue structure of all of the categories of local government units is that of cities with powiat rights. The budget revenue of local government units affects these entities' expenditure capacity.

\footnotetext{
${ }^{1}$ Local government units' budgets also contain supplementary revenue sources, which may be transferred from the central state budget, budgets of other local government units and from other public funds. They may have the form of a general subvention or subsidies.
} 


\section{Table 1}

Share of own revenue in local government units' total revenue in 2007-2016 (\%)

\begin{tabular}{lcccccccccc}
\hline Item & 2007 & 2008 & 2009 & 2010 & 2011 & 2012 & 2013 & 2014 & 2015 & 2016 \\
\hline All local government units & 56.4 & 55.0 & 48.6 & 48.3 & 48.8 & 49.1 & 50.0 & 50.7 & 52.0 & 49.9 \\
Gminas & 49.5 & 49.3 & 46.3 & 44.6 & 45.5 & 46.6 & 48.2 & 49.3 & 49.7 & 44.3 \\
Cities with powiat rights & 70.3 & 69.5 & 66.1 & 63.6 & 63.2 & 61.1 & 62.4 & 62.8 & 63.5 & 61.6 \\
Powiats & 32.2 & 32.4 & 28.4 & 28.2 & 27.7 & 29.4 & 29.9 & 31.3 & 33.5 & 35.4 \\
Voivodships & 68.3 & 58.5 & 32.3 & 40.4 & 44.3 & 43.0 & 39.1 & 36.9 & 41.8 & 53.4 \\
\hline
\end{tabular}

Source: author's own work based on Reports of the Council of Ministers on the accomplishment of the state

budget in 2007-2016. Information on the accomplishment of local government units' budgets.

The budget expenditure of local government units satisfies the collective needs of local and regional communities. The directions of spending budgetary funds depend on expenditure priorities which are set within the catalogue of public tasks entrusted to local government units for completion. Among local government units' budgetary expenditure one may distinguish capital and current expenditure (Act on Public Finance, consolidated text 2017, art. 236). The key role in the creation of the social and economic development of a local government unit is played by capital expenditure as they allow financing investment undertakings. When analysing the share of capital expenditure in local government units' total expenditure structure in 2007-2016 (Table 2) one must stress that the greatest share was reported in gminas in 2010 (25.1\%), in cities with powiat rights in $2009(23.0 \%)$, in powiats in 2010 (21.8\%), and in voivodships in 2009 (48.7\%). The higher the share of the capital category in the total revenue, the lower the share of the current revenue in the total revenue figures.

\section{Table 2}

The share of capital expenditure in total expenditure by categories of local government units in $2007-2016(\%)$

\begin{tabular}{lllllllllll}
\hline Item & 2007 & 2008 & 2009 & 2010 & 2011 & 2012 & 2013 & 2014 & 2015 & 2016 \\
\hline All local government units & 21.0 & 22.0 & 25.7 & 24.9 & 23.4 & 19.7 & 19.0 & 21.0 & 19.6 & 12.5 \\
Gminas & 18.8 & 20.5 & 23.1 & 25.1 & 22.9 & 18.1 & 16.6 & 18.2 & 16.9 & 11.2 \\
Cities with powiat rights & 22.5 & 22.7 & 23.0 & 22.3 & 21.2 & 19.9 & 19.1 & 20.9 & 18.5 & 11.9 \\
Powiats & 13.1 & 14.5 & 19.3 & 21.8 & 18.7 & 12.5 & 12.5 & 14.7 & 14.6 & 12.9 \\
Voivodships & 36.7 & 36.7 & 48.7 & 39.0 & 40.5 & 37.8 & 39.7 & 43.0 & 45.1 & 26.2 \\
\hline
\end{tabular}

Source: author's own work based on Reports of the Council of Ministers on the accomplishment of the state budget in 2007-2016. Information on the accomplishment of local government units' budgets.

In the local government units' finance management system there are both positive and negative budget results and it is hard to clearly assess each of them as one needs to examine the causes. The presence of a budget deficit is combined with a situation where local 
government units spend more than they collect as budget revenue (cf. Sołtyk, DębowskaSołtyk, 2016, pp. 84-88). The opposite of a deficit is a budget surplus, which is not always evidence for a properly managed finance system as its source may be, for instance, only the partial accomplishment of tasks. When analysing the budget results of local government units in 2007-2016 (Table 3) one must conclude that the positive results were observed both for individual categories of local government units as for the entire groups of these entities in 2007 and in 2016. Additionally, such results were generated by gminas in 2013 and in 2015, cities with powiat rights in 2015, powiats in 2008 and in 2012-2013 and in 2015 while the local government units as a whole in 2015. Other observations constitute evidence for the negative result in total, which reached the highest value in gminas, powiats and for all local government units in 2010, in cities with powiat rights in 2009 and in voivodships in 2011.

\section{Table 3}

Total budget results by categories of local government units in 2007-2016 (million PLN)

\begin{tabular}{|c|c|c|c|c|c|c|c|c|c|c|}
\hline Item & 2007 & 2008 & 2009 & 2010 & 2011 & 2012 & 2013 & 2014 & 2015 & 2016 \\
\hline $\begin{array}{l}\text { All local government } \\
\text { units }\end{array}$ & 2258 & -2602 & -12986 & -14970 & -10286 & -3046 & -380 & -2417 & 2604 & 7634 \\
\hline Gminas & 923 & -578 & -5120 & -7430 & -3856 & -84 & 601 & -521 & 1723 & 3620 \\
\hline $\begin{array}{l}\text { Cities with powiat } \\
\text { rights }\end{array}$ & 997 & -1720 & -5874 & -5069 & -4650 & -2484 & -736 & -1402 & 736 & 2479 \\
\hline Powiats & 85 & 32 & -1071 & -1330 & -507 & 46 & 161 & -1 & 237 & 648 \\
\hline Voivodships & 253 & -337 & -920 & -1141 & -1272 & -525 & -406 & -493 & -93 & 888 \\
\hline
\end{tabular}

Source: author's own work based on Reports of the Council of Ministers on the accomplishment of the state budget in 2007-2016. Information on the accomplishment of local government units'budgets.

\section{Table 4}

Operating surplus by categories of local government units in 2007-2016 (million PLN)

\begin{tabular}{lrrrrrrrrrr}
\hline Item & 2007 & 2008 & 2009 & 2010 & 2011 & 2012 & 2013 & 2014 & 2015 & 2016 \\
\hline $\begin{array}{l}\text { All local govern- } \\
\quad \text { ment units }\end{array}$ & 17719 & 17739 & 11960 & 9284 & 10994 & 11626 & 14337 & 16318 & 18228 & 20526 \\
$\begin{array}{l}\text { Gminas } \\
\text { Cities with po- }\end{array}$ & 7196 & 8075 & 6191 & 4687 & 5426 & 6241 & 7340 & 8097 & 8731 & 10361 \\
$\quad$ wiat rights & 6794 & 5760 & 2982 & 2503 & 2788 & 2572 & 4152 & 5155 & 5849 & 6195 \\
Powiats & 976 & 1099 & 883 & 780 & 1268 & 1092 & 1256 & 1496 & 1613 & 2063 \\
$\quad$ Voivodships & 2753 & 2804 & 1904 & 1313 & 1512 & 1721 & 1588 & 1571 & 2034 & 1906 \\
\hline
\end{tabular}

Source: author's own work based on Reports of the Council of Ministers on the accomplishment of the state budget in 2007-2016. Information on the accomplishment of local government units' budgets. 
In 2007-2016 all the analysed local government units reported positive results ${ }^{2}$, which means they revealed an operating surplus (Table 4). Along with the capital result the surplus make up the total result. When comparing the operating surplus with the total result one may spot how significant deficit, in the capital part related to the accomplishment of investment projects, was reported by local government units.

Operating surplus proves that the situation of the local government unit is strong and the surplus positively contributes to the capacity for assuming new financial obligations. The reason for reporting the operating surplus is the introduction of the principle of balancing the local government unit's budget in the current portion, which was applied for the first time in 2011. The finance management constitutes the financial base of local government units and affects the development of other areas of their operations.

\section{Conditions of the Operations of Local Government Units}

The operations of local government units are determined by a series of interrelated factors, which in particular include: financial, social and economic, legal, political and administrative factors.

Those of key importance are the financial factors related to the unit's budget situation. They include particularly the share of own revenue in total revenue and the share of capital expenditure in total expenditure. Additionally, it is necessary to consider the budget result including the division into the operating (current) and capital parts. These issues have been described more extensively in the previous section.

Another group is constituted by social and economic factors. They include all factors which affect the social and economic development of a local government unit. An item worth pointing out is the living conditions of local people. The local government unit authorities should, in particular, undertake actions to decrease the unemployment rate and increase employment in their area, which is a direct public task to be performed by powiats and voivodships. Further important tasks are actions to encourage young people to continue their education in post-secondary schools - general or vocational - as graduates of those schools find it easier to get jobs. Public education tasks are performed by all local government units.

The next group is made up by legal factors. They include joint regulations that determine the conditions of local government units' operations specified in the Constitution of the Republic of Poland, ratified international agreements, acts and regulations as well as laws and regulations adopted by individual local government units in the form of local legal acts.

A further group is formed by political and administrative conditions among which an important factor is the experience of local government units in the efficient and effective acquisition of funds to cover the performance of public tasks, regardless of the source of

\footnotetext{
${ }^{2}$ The difference between current revenue and current expenditure.
} 
financing (cf. Alińska, Dworakowska, 2015). Additionally, what matters here is the ability to conduct and account for the performed projects complying with all the requirements. The local government unit must also have a development policy and its authorities must focus on following the provisions of this development policy taking into account the activities undertaken by local decision-makers to fulfil pre-election promises, which not always reflects the most urgent expenditure needs of the local government unit.

It is necessary to comprehensively take into account the specified conditions and treat them as top priorities.

\section{Major Changes in the Economic Surrounding of Local Government Units}

The economic environment of local government units is changing dynamically. The units must be able to react to new challenges coming from the economic surrounding. In the context of local government units' finances, one must point to the series of changes in their economic surrounding which in the past few years particularly distinctly affected the functioning conditions of those entities. Due to the natural constraints of this article, the analysis shall cover only the major changes.

The first of those changes is the state actions, observed in the past few years, resulting in the expansion of the number of public tasks entrusted to local government units, particularly gminas, as they are the entities with default competence for those tasks as stated in the Polish constitution.

This gives the local government units the possibility to decide upon a larger and larger range of tasks. However, it at the same time requires them to ensure funds to cover the expenditure to pay for the entire range of tasks. A significant problem for the finance management system of local government units is the formulation of new tasks and expansion of the scope of tasks so far performed without securing necessary funds for this purpose, which results in deficits reported in the finance management system of local government units. In such a situation it is necessary to select between the deterioration of the task performance standards, particularly in the case of costly and comprehensive projects, and financing - from other sources - of tasks with underestimated cost calculations, meaning the cost of other expenditure. The state seemingly is continuously contributing to the trend of expanding the types of tasks performed by local government units. ${ }^{3}$

The second change is the local government units' dependence on transfer revenue. These are supplementary revenue which, along with own revenue; make up the total budget

\footnotetext{
${ }^{3}$ An example is the maintenance of the "Rodzina 500 plus" program the performance of which is attributed to gminas predominantly. They perform numerous obligations related to the operation of this family benefit system. As early as in January 2016 during the sitting of the Joint Committee of Central and Local Governments local officials pointed particularly to the fact that the amounts allocated to the maintenance of this task are insufficient compared to the scale of the undertaking, as it will frequently require the hiring and training of new employees, ensure working space for them, etc. Cf. Gniadkowski (2016).
} 
revenue. They comprise the general subvention granted on the basis of objective criteria and total subsidies which include targeted grants awarded discretionally. Thus, the general subvention constitutes the best source of finances for local government units. Another form of transfers to local government units is also the share in central budget taxes which, in the Polish legal regulations are treated as a category of own revenue. However, such a classification is artificial as gminas, powiats, and voivodships do not have any authority to shape those amounts. The dominant share of transfer revenue in the total revenue structure proves the local government unit is dependent on the state. This is manifested, among others, by the stronger reactions of local government units to those changes within the state finance situation which are the most unfavourable in the light of deteriorating economic dynamics. Additionally, the dependence grows even further along with increasing transfer shares as the purpose of those transfers are determined by the subsidiser.

The third change is the possibility to absorb funds from foreign sources. The local government units' ability to use non-refundable grants from structural funds and form a Cohesion Fund offers opportunities to accomplish numerous costly projects. EU funds constitute an exceptionally important source of co-financing and contribute, in particular, to the improvement of the condition of infrastructure, a flattening of the disproportional development of local government units, to faster local and regional development. The funds are granted in accordance with the principle of additionality and the expenditure is refunded only when a project is completed. The obligatory own contribution of the beneficiary, particularly with vast and costly investment undertakings may reach high amounts and this represents a significant constraint for local government units applying for non-refundable EU funds. The forecasted total own contributions of local government units in 2014-2020, which will be necessary to obtain the co-financing of projects from EU sources, will total as much as 60.62 billion PLN, while the total EU funds allocated to local government units amounting to 107.2 billion PLN (Sierak et al., 2013, p. 9). These data represent the scale of local government units' demand for financing. Here one must remember about the instability inside the EU, which is a community of states, evoked particularly by Brexit and the migration crisis. This may translate into an adjustment of the priorities of the EU structural policy and consequently, a change of the funds' allocation (cf. Poniatowicz, 2016, p. 20).

The fourth change is constituted by the limited possibilities of local government units to assume debts. 1 January 2014 was the date of the implementation of individual debt ratios calculated for each local government unit. Their structure refers to historical data from the past three years and is based mainly on the operating surplus value. Assuming debt is the primary way of gathering external funds, particularly taking of loans and credits for the accomplishment of investment projects in local government units. In this context one must refer to the issue of local government units' performing a larger and larger variety of tasks. Whether these tasks are completed or not depends not only on the acquired budget funds and expenditure incurred, but also on the debt limits in force, which allow or limit the possibility of using debt sources of task financing, particularly in the case of investment 
tasks. The growing debt balance of local government units largely results from the fact that they are conducting investment projects for which there are no budget funds and which require refundable financing. Additionally, the completion of investment projects co-financed by the EU budget frequently requires the assumption of debt obligations that will need to be repaid in the future and which consume a significant portion of budget funds. The introduction of the rigorous debt limits may result in decreasing the absorption of EU funds by local government units, which would adversely affect local and regional development.

The fifth change is represented by frequent amendments to legal regulations and inflation of laws regulating the functioning of local government units. Legal regulations form the framework of local government units' operations, but do not constitute a stable and transparent system of law sources. The regulations lack precision, clarity and a comprehensiveness of the issues they apply to. Frequent changes of and gaps in the regulations impair the operations of local government units and negatively impact local and regional finance stability.

The sixth change is reflected by the impact of the economic crisis which began in 2007 in the United States of America, and which quickly spread to other continents and also reached EU states, including Poland. It affected the banking sector and its consequences resulted in difficulties in the functioning of the entire financial system. Some consequences of the crisis were mitigated by European institutions and mechanisms, an example of which may be EU structural funds. In the light of the economic crisis the EU aid funds played an important role and allowed preserving, in 2008-2010, the high involvement of Polish local government units in the completion of investment projects.

\section{Conclusions}

To sum up, the operations of local government units require the management of finance and funds distribution among other public tasks, which fairly frequently compete with one another. Budget revenue and the expenditure of local government units are diverse, which is a consequence of, among others, different levels of social and economic development of various areas of the country. The relations between revenue and expenditure make it possible to analyse the budget balancing of these entities. The financial conditions of gminas, cities with powiat rights, powiats and voivodships influence all of the aspects of local government units' functioning.

The conducted analyses revealed conditions of the operations of local government units in Poland during the 2007-2016 period in the context of the finances of these entities. The collected data prove there were frequent changes made to the economic surrounding of local government units which require relevant reactions to new challenges. An unstable economic environment shapes the conditions of the functioning of local government units. 


\section{References}

Act on Public Finance of 27 August 2009, consolidated text Journal of Laws 2017, item 2077, with further amendments.

Alińska, A., Dworakowska, M. (2015). Finanse jednostek samorządu terytorialnego. In: A. Alińska, B. Woźniak (Eds.), Wspótczesne finanse publiczne (pp. 221-295). Warszawa: Difin.

Głowicka-Wołoszyn, R., Wołoszyn, A., Kozera, A. (2017). Nierówności dochodowe samorządów gminnych w Polsce. Nierówności Społeczne a Wzrost Gospodarczy, 49, pp. 396-405.

Gniadkowski, A. (2016). Rodzina $500+w$ Sejmie, akty wykonawcze gotowe - ważne oświadczenie samorząów. Downloaded from: www.wspolnota.org.pl/aktualnosci/aktualnosc/rodzina-500-w-sejmie-akty-wykonawczegotowe-wazne-oswiadczenie-samorzadow/ (30.03.2018).

Poniatowicz, M. (2016). Stabilność finansowa jednostek samorządu terytorialnego w aspekcie nowej perspektywy finansowej Unii Europejskiej i zmian w systemie dochodów samorządowych. Ekonomiczne Problemy Ustug, 125 , pp. 7-23.

Reports of the Council of Ministers on accomplishment of state budget in 2007-2016. Information on the accomplishment of local government units' budgets.

Sierak, J., Bitner, M., Gałązka, A., Górniak, R. (2013). Oszacowanie środków niezbędnych do zapewnienia krajowego wkładu publicznego do projektów realizowanych w ramach średniookresowych ram finansowych 2014-2020. Warszawa: Ministerstwo Rozwoju Regionalnego.

Sołtyk, P., Dębowska-Sołtyk, M. (2016). Finanse samorządowe. Warszawa: Difin.

\section{UWARUNKOWANIA DZIALALNOŚCI JEDNOSTEK SAMORZĄDU TERYTORIALNEGO W NIESTABILNYM OTOCZENIU GOSPODARCZYM}

Streszczenie: $\mathrm{Cel}$ - Celem artykułu jest przedstawienie uwarunkowań działalności jednostek samorządu terytorialnego w Polsce w latach 2007-2016 z perspektywy finansów tych podmiotów. Rozważania są prowadzone $\mathrm{z}$ uwzględnieniem najważniejszych zmian w otoczeniu gospodarczym jednostek samorządu terytorialnego, które zachodziły w ostatnich latach.

Metodologia badania - Złożony obszar badawczy wymaga użycia różnych metod badawczych, aby osiągnąć wyznaczony cel. W procedurze badawczej wykorzystano metody badań niereaktywnych, zastosowano metodę historyczno-porównawczą i metodę analizy dokumentów urzędowych.

Wynik - Dokonane analizy pozwoliły wskazać uwarunkowania działalności jednostek samorządu terytorialnego w Polsce w latach 2007-2016 w kontekście finansów tych podmiotów. Zebrane dane świadczą o częstych zmianach w otoczeniu gospodarczym jednostek samorządu terytorialnego, które wymagają odpowiedniego reagowania na nowe wyzwania. Niestabilne otocznie gospodarcze kształtuje warunki działania gmin, miast na prawach powiatu, powiatów i województw. Tym samym oddziałuje w szczególny sposób na działalność jednostek samorządu terytorialnego.

Oryginalność/wartość - Analiza badanej problematyki potwierdza, że na działalność jednostek samorządu terytorialnego oddziałują różnorodne bodźce, których źródłem jest otoczenie gospodarcze. Podlegało ono w ostatnich latach dynamicznym zmianom, które wymagały reagowania przez podmioty sektora samorządowego i odpowiedzi na rodzące się wyzwania. Działalność jednostek samorządu terytorialnego jest determinowana przez grupę powiązanych ze sobą uwarunkowań. Analiza działalności jednostek samorządu terytorialnego w Polsce w latach 2007-2016 wskazuje, że finanse są podstawową funkcjonowania każdej jednostki samorządu terytorialnego oraz wyznacznikiem realności i powodzenia realizowanych zadań publicznych.

Słowa kluczowe: uwarunkowania działalności, jednostki samorządu terytorialnego, otoczenie gospodarcze, finanse

\section{Citation}

Dworakowska, M. (2018). Conditions of the Operations of Local Government Units in Unstable Economic Environments. Finanse, Rynki Finansowe, Ubezpieczenia, 2 (92), 457-465. DOI: 10.18276/frfu.2018.92-39. 